\title{
Purification of $\alpha$-Galactosidase from Coconut Endosperm by Affinity Chromatography
}

\author{
K. Balasubramaniam \\ Department of Biochemistry, University of Jaffna, Kaithady, Jaffna, Sri Lanka \\ AND \\ C. D. Mathew \\ Department of Biochemistry, University of Colombo, Kynsey Road, Colombo 8, Sri Lanka
}

(Date of receipt: 02 May 1984)

(Date of acceptance: 19 July 1984)

\begin{abstract}
Four specific adsorbants for the purification of $\alpha$-galactosidase ( $\alpha$-D galactoside galactohydrolase EC 3.21 .22 ) from coconut endosperm were prepared. The affinity gels prepared were Sepharose-4B-lysine-galacturonate, Sepharose-4B-lysinegalactosamine, Sepharose-4B-lysine-galactose-p-carboxyanilide and $\mathrm{CH}$-Sepharose4B-galactosamine. $\%$-Galactosidase from coconut endosperm extract was partially purified by ammonium sulphate fractionation, DEAE-Sephadex chromatography and this partially purified preparation was further purified by affinity chromatography using these specific adsorbants. The adsorbed $\alpha$-galactosidase was eluted either by using a linear gradient of increasing buffer concentration or by using the specific desorbant $\mathrm{p}$-nitrophenyl- $\alpha$-D-galactopyranoside. The specific activity of the purified enzyme tested with p-nitrophenyl- $\alpha$-D-galactopyranoside as substrate was 20 units $/ \mathrm{mg}$ protein. This represents a 900 fold increase in purification of the original crude extract and the yield was $67 \%$. The purified enzyme was homogeneous by polyacrylamide gel electrophoresis.
\end{abstract}

\section{Introduction}

$\alpha$-Galactosidases ( $\alpha$-D-galactosyl galactohydrolase E.C. 3.2.1.22) are widely distributed in nature and are commonly found in plant seeds. ${ }^{21}$ Polysaccharides and oligosacchadrides containing $\alpha$-D-galactosyl units accumulate in seeds during maturation and serve as storage products in resting seeds. ${ }^{7}$ During germination oligosaccharides are utilized first followed by the polysaccharides. D-galactose, the initial product of hydrolysis is rapidly transformed and utilized through the glycolytic pathway and is an important source of energy for the growing seedling. ${ }^{8}$

$\alpha$-Galactosidase is an important enzyme in the coconut endosperm as raffinose is the predominant oligosaccharide and galactomannans, the major $(61 \%)$ polysaccharide. ${ }^{1}$ Balasubramaniam et $a l^{2}$ showed the presence of two interconvertible $\alpha$-galactosidase isoenzymes in the coconut kernel. The authors have purified the low molecular weight isoenzyme from coconut kernel to homogeneity and characterized it. ${ }^{3}$ However the yield was only $12 \%$ and the amount of pure enzyme obtained was insufficient for studies to elucidate the mechanism of its 
action. $a$-Galactosidase from coffee beans ${ }^{11}$ and from human serum ${ }^{13}$ have been purified by affinity chromatography using $\alpha$-D-galactosylamine and Melibiose as affinity ligands.

In this paper the purification of $\alpha$-galactosidase by affinity chromatography using galactosamine, galacturonic acid and galactose-p-carboxyanilide as affinity ligands is described.

\section{Materials and Methods}

Analytical grade BDH and Sigma Chemicals were used. Mature fresh coconuts were purchased locally. Sepharose 4B, CH-Sepharose-4B and DEAE-Sephadex A-25 were purchased from Pharmacia fine Chemicals. Cyanagen bromide was synthesized in the laboratory. ${ }^{14}$

Absorbance was measured using a Pye Unicam SP 800 UV Spectrophotometer. Centrifugation was carried out in an IEC B 20A refrigerated centrifuge.

\subsection{Enzyme assay}

$\alpha$-Galactosidase activity was assayed as described by Dey and Pridham. ${ }^{10}$ Suitably diluted enzyme preparation $(0.1 \mathrm{ml})$ were incubated at $30^{\circ} \mathrm{C}$ with $0.5 \mathrm{ml}$ of p-nitrophenyl- $\alpha$-D-galactopyranoside $(1 \mathrm{mM})$ and $0.4 \mathrm{ml}$ of $0.08 \mathrm{M}$ Mcllvaine buffer ${ }^{18}$ (pH 5.5) for $15 \mathrm{~min}$. The reaction was terminated by the addition of $0.1 \mathrm{M}$ $\mathrm{Na}_{2} \mathrm{CO}_{3}(5 \mathrm{ml})$ and absorbance measured at $405 \mathrm{~nm}$. A unit of enzyme activity is defined as the amount of enzyme that hydrolyses $1 \mu$ mole of substrate/min under these given conditions.

\subsection{Protein estimation}

Protein content was determined by the method of Lowry et al ${ }^{16}$. using crystalline bovine serum albumin as standard or by measuring the absorbance at $280 \mathrm{~nm}$.

\subsection{Estimation of sugars}

Galacturonic acid, galactosamine and galactose-p-carboxyanilide in the washings were determined by the Dubois ${ }^{11}$ method using authentic samples of the same sugars as standards.

\subsection{Synthesis of galactose-p-carboxyanilide}

Galactose-p-carboxyanilide was synthesized as described by Honeyman. ${ }^{15}$ Thin layer chromatography was done on the synthesized material as described by Stahl et al. ${ }^{20}$. The synthesized material gave a single spot on thin layer chromatography. 
2.5 Inhibition of $\alpha$-galactosidase by galactose-p-carboxyanilide, galactosamine and galacturonic acid

$\alpha$-Galactosidase was incubated with constant concentrations of galactose-pcarboxyanilide $(1 \mathrm{mM})$, galactosamine $(10 \mathrm{mM})$ and galacturonic acid $(6 \mathrm{mM})$ in $0.08 \mathrm{M}$ Mcllvaine buffer ( $\mathrm{pH} 5.5$ ) and with varying concentrations of substrate $\left(2 \times 10^{-4}\right.$ to $\left.5 \times 10^{-4} \mathrm{M}\right)$. The p-nitrophenol released was determined as described in section 2.2 .

\subsection{Preparation of Sepharose-4B-lysine}

Activation of Sepharose-4B and binding of lysine was done as described by Cuatrecasas. ${ }^{6}$ Sepharose-4B ( $7 \mathrm{ml}$ packed volume) was washed and suspended in $3 \mathrm{~m}$ of distilled water. The suspension was held in an ice bath and stirred (continuously) with a glass rod. $\mathrm{CNBr}$ (in warm distilled water) was added to the suspension and the $\mathrm{pH}$ maintained at 11 for $15 \mathrm{~min}$ by the addition of $10 \mathrm{~N} \mathrm{NaOH}$. The activated gel washed with cold $0.2 \mathrm{M} \mathrm{NaHCO}$ ( $\mathrm{NH}^{8.5}$ ) was suspended in the same buffer. Lysine ( $0.2 \mathrm{~m}$ moles) dissolved in $6 \mathrm{ml}$ of 0.2 of $\mathrm{M} \mathrm{NaHCO}_{3}(\mathrm{pH} \mathrm{8.5)}$ was added to the suspension and mixed 'end over end' overnight at $6^{\circ} \mathrm{C}$. The gel was washed with the same buffer. The washings were collected and the lysine content was determined using ninhydrin. ${ }^{19}$ Sepharose-4B-lysine was prepared in batches and the lysine content was varied by changing the amount of $\mathrm{CNBr}$ used.

\subsection{Preparation of Sepharose-4B-lysine-galactouronate gel}

Lysine bound Sepharose-4B (Section 2.6) was washed with distilled water and stirred in $3 \mathrm{ml}$ distilled water at room temperature $\left(29^{\circ} \mathrm{C}\right)$. Galacturonic acid $(0.5 \mathrm{mmoles})$ was added in $3 \mathrm{ml}$ of distilled water to $1 \mathrm{~m}$ mole of 1-ethyl-3-(3-dimethyl aminopropyl) carbodiimide. The $\mathrm{pH}$ was maintained at 4.5 for $6 \mathrm{~h}$ by addition of $0.1 \mathrm{~N}$ $\mathrm{HCl}$. The gel was washed with distilled water and the galacturonic acid content in the washings was determined by the Dubois ${ }^{11}$ method.

\subsection{Preparation of Sepharose-4B-lysine-galactosamine gel}

Sepharose-4B-lysine (Section 2.6) and galactosamine (0.15 m moles) were coupled using 0.3 mmoles of 1-ethyl-3-(3-dimethyl aminopropyl) carbodiimide as described in Section 2.7 .

\subsection{Preparation of Sepharose-4B-lysine-galactose-p-carboxyanilide gel}

Sepharose-4B-lysine (Section 2.6) and $1 \mathrm{~m}$ mole of galactose-p-carboxyanilide in $25 \mathrm{ml}$ of $40 \%$ dimethyl formamide were coupled using $2 \mathrm{~m}$ moles of 1-ethyl-3 (3-dimethyl aminopropyl) carbodiimide as described in Section 2.7 but washing was done with $40 \%$ dimethyl formamide. 


\subsection{Preparation of CH-Sepharose-galactosamine gel}

CH-Sepharose-4B (1.5 g) was swelled in $0.5 \mathrm{~m} \mathrm{NaCl}$ and washed with $0.5 \mathrm{M} \mathrm{NaCl}$ followed by distilled water. Coupling of galactosamine was carried out as in Section 2.7 using $0.15 \mathrm{~m}$ moles of galactosamine and $0.3 \mathrm{~m}$ moles of 1-ethyl-3(3-dimethyl aminopropyl) carbodiimide.

\subsection{Purification of $\alpha$-galactosidase}

All operations were carried out at room temperature $\left(29^{\circ} \mathrm{C}\right)$ unless specified otherwise. Centrifugation was carried out at $4^{\circ} \mathrm{C}$. Fractions collected after column chromatography were assayed for enzyme activity (Section 2.2) and the protein concentrations of each fraction was determined by measuring the absorbance at $280 \mathrm{~nm}$.

\subsubsection{Extraction}

Coconut kernel scrapings were homogenized in McIlvaine buffer (pH 5.5) using a Waring blender. The extract $(2 \mathrm{ml} / \mathrm{g})$ was passed through a cheese cloth and centrifuged at $25000 \mathrm{~g}$ for $20 \mathrm{~min}$. The supernatant obtained was adjusted to pH 3.8 using $0.5 \mathrm{M}$ citric acid. On standing for $30 \mathrm{~min}$ the acidified solution was centrifuged at $25000 \mathrm{~g}$ for $20 \mathrm{~min}$. The $\mathrm{pH}$ of the acid supernatant was readjusted to $\mathrm{pH} 5.5$ using saturated solution of $\mathrm{Na}_{2} \mathrm{HPO}_{4}$.

\subsubsection{Ammonium sulphate fractionation}

The acid supernatant ( $\mathrm{pH}$ 5.5) was fractionated using solid ammonium sulphate. The precipitate collected between $45-60 \%$ saturation was dissolved in Mcllvaine buffer ( $\mathrm{pH} 5.5$ ) and dialysed against $0.008 \mathrm{M}$ McIlvaine buffer ( $\mathrm{pH} 5.5$ ).

\subsubsection{DEAE-Sephadex A-25 gel chromatography}

$\alpha$-Galactosidase from ammonium sulphate fractionation step (40 mg in $60 \mathrm{ml}$ ) was applied to a column of DEAE-Sephadex A-25 $(2.4 \times 28 \mathrm{~cm})$ previously equilibrated with $0.008 \mathrm{M}$ Mcllvaine buffer ( $\mathrm{pH}$ 5.5). The column was washed with $60 \mathrm{ml}$ of the same buffer. The column was eluted with a $2: 1$ gradient consisting of $0.008 \mathrm{M}(200 \mathrm{ml})$ and $0.16 \mathrm{M}(100 \mathrm{ml})$ McIlvaine buffer $(\mathrm{pH} \mathrm{5.5)}$. The fractions containing enzyme activity were pooled and dialysed against $0.008 \mathrm{M}$ Mcllvaine buffer ( $\mathrm{pH}$ 5.0).

\subsubsection{Sepharose-4B--lysine-galacturonic acid gel chromatography}

To Sepharose-4B-lysine-galactouronate gel $(0.5 \times 3 \mathrm{~cm})$ was applied $2 \mathrm{ml}(0.1 \mathrm{mg})$ of DEAE-Sephadex A-25 eluted enzyme (Section 2.11.3). The gel had been equillibrated with $0.008 \mathrm{M}$ McIlvaine buffer ( $\mathrm{pH} 5.0$ ). After application allowed a period of $15 \mathrm{~min}$ for the adsorption of the enzyme. The column was eluted with $8 \mathrm{ml}$ of the same buffer and later with the same volume of $0.08 \mathrm{M}$ Mcllvaine buffer (pH 5.0). 


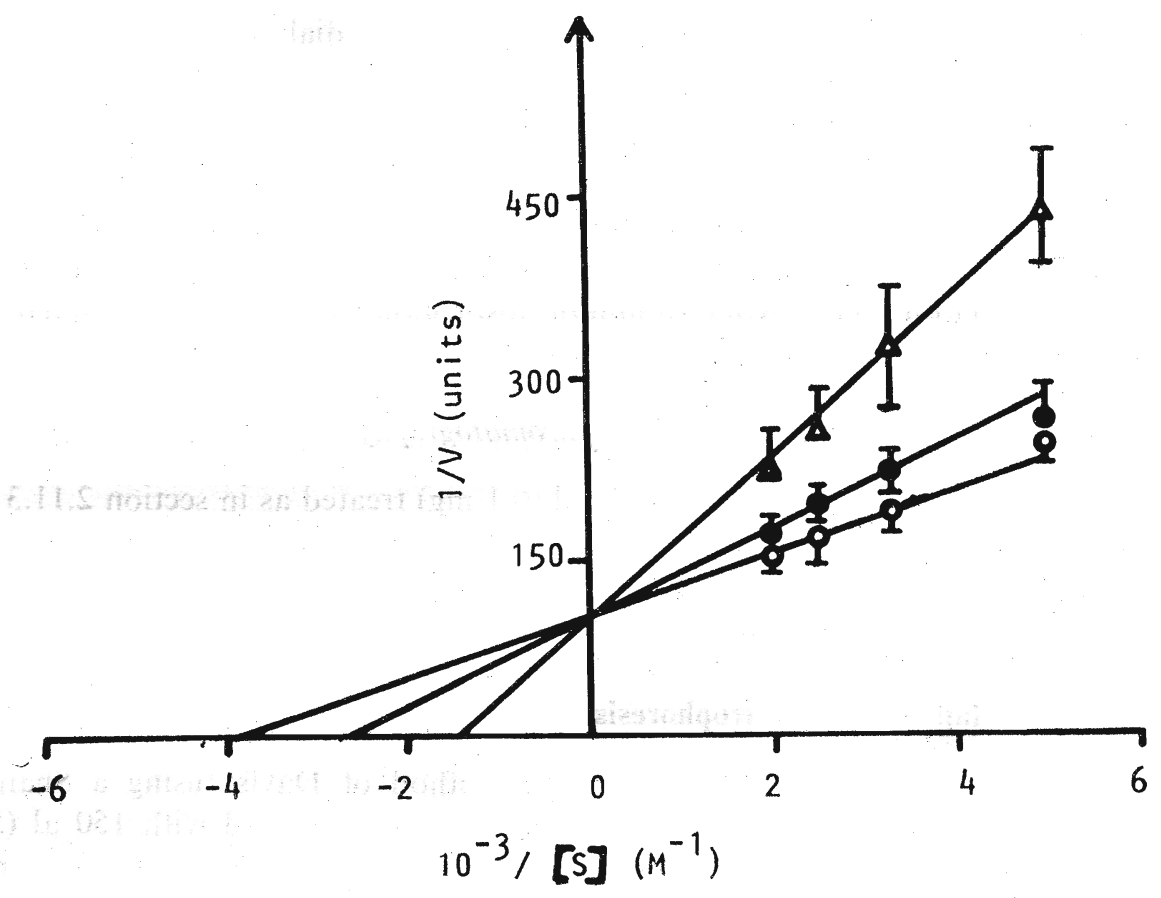

Figure 1: Lineweaver-Burk plot for the inhibition of $\alpha$-galactosidase by galacturonic acid and galactose-p-carboxyanilide. $O$, none; $O^{\prime}$ galacturonic acid $(10 \mathrm{mM}) ; \Delta$, galactose-p-carboxyanilide $(1 \mathrm{mM})$. Bars indicate standard deviations obtained from four experiments. No inhibition was observed when galactosamine $(10 \mathrm{mM})$ was used. 


\subsubsection{Sepharose-4B-lysine-galactose-p-carboxyanilide gel chromatography}

To Sepharose-4B-lysine-galactose-p-carboxyanilide column $(0.5 \times 9.0 \mathrm{vm})$ equillibrated with $0.008 \mathrm{M}$ Mcllvaine buffer ( $\mathrm{pH} 5.0$ ) was applied $2 \mathrm{ml}$ of DEAE-Sephadex A-25 eluted enzyme $(0.1 \mathrm{mg})$ prepared as in section 2.11.3. After $15 \mathrm{~min}$ of adsorption the enzyme was eluted with $30 \mathrm{ml}$ of $0.008 \mathrm{M}$ Mcllvaine buffer (pH 5.0) and $15 \mathrm{ml}$ of $0.1 \mathrm{M}$ McIlvaine buffer ( $\mathrm{pH} 5.0$ ). At this point $1 \mathrm{ml}$ of $20 \mathrm{mM}$ p-nitrophenyl- $\alpha$-D-galactopyranoside was applied to the column and eluted with $15 \mathrm{ml}$ of $0.1 \mathrm{M}$ Mcllvaine buffer ( $\mathrm{pH} 5.0$ ). The eluate was dialysed against the same buffer and assayed for enzyme activity.

\subsubsection{Sepharose-4B--lysine-galactosamine gel chromatography}

To the Sepharose-4B-lysine-galactosamine gel equillibrated with $0.008 \mathrm{M}$ McIlvaine buffer ( $\mathrm{pH} 5.0$ ) was applied $2 \mathrm{ml}$ of DEAE-Sephadex A-25 eluted enzyme $(0.1 \mathrm{mg}$ ) treated as in section 2.11.3. After 15 min of adsorption the enzyme was eluted with the same buffer.

\subsubsection{CH-Sepharose-galactosamine gel chromatography}

DEAE-Sephadex A-25 eluted enzyme $2 \mathrm{ml}(0.1 \mathrm{mg})$ treated as in section 2.11 .3 was applied to the $\mathrm{CH}-$ Sepharose-galactosamine gel equilibrated with $0.008 \mathrm{M}$ Mcllvaine buffer ( $\mathrm{pH} \mathrm{5.0)}$ ). Allowed for $15 \mathrm{~min}$ and eluted with $25 \mathrm{ml}$ of the same buffer and $30 \mathrm{ml}$ of $0.1 \mathrm{M}$ McIlvaine buffer ( $\mathrm{pH} 5.0$ ).

\subsection{Polyacrylamide gel electrophoresis}

The electrophoresis was carried out by the method of Davis ${ }^{6}$ using a Shandon apparatus. Polyacrylamide gels $(5 \%)$ were prepared and loaded with $150 \mu \mathrm{l}(5 \mu \mathrm{g}$ protein) of the purified enzyme (diluted 2:1 with glycerol). Mcllvaine buffer $\mathrm{pH}$ 6.5 was used in the reservoir. Gels were stained for proteins using Coomassie Brilliant Blue. $\alpha$-Galactosidase activity was determined by incubating with 4-methyl umbelleferyl- $\alpha$-D-galactoside $(2.5 \mathrm{mM})$ at room temperature for $30 \mathrm{~min}$. The reaction was terminated with $0.5 \mathrm{M} \mathrm{NaOH}$ and the fluorescent bands were observed under UV-light.

\section{Results}

\subsection{Inhibition of $\alpha$-galactosidase}

Galacturonic acid and galactose-p-carboxyanilide, are competitive inhibitors of $\alpha$-galactosidase while galactosamine did not inhibit the enzyme at a concentration of $10 \mathrm{mM}$ (Figure 1). The Ki values calculated from the graph were $2 \times 10^{-2} \mathrm{M}$ and $1.8 \times 10^{4} \mathrm{M}$ for galacturonic acid and galactose-p-carboxyanilide respectively. 


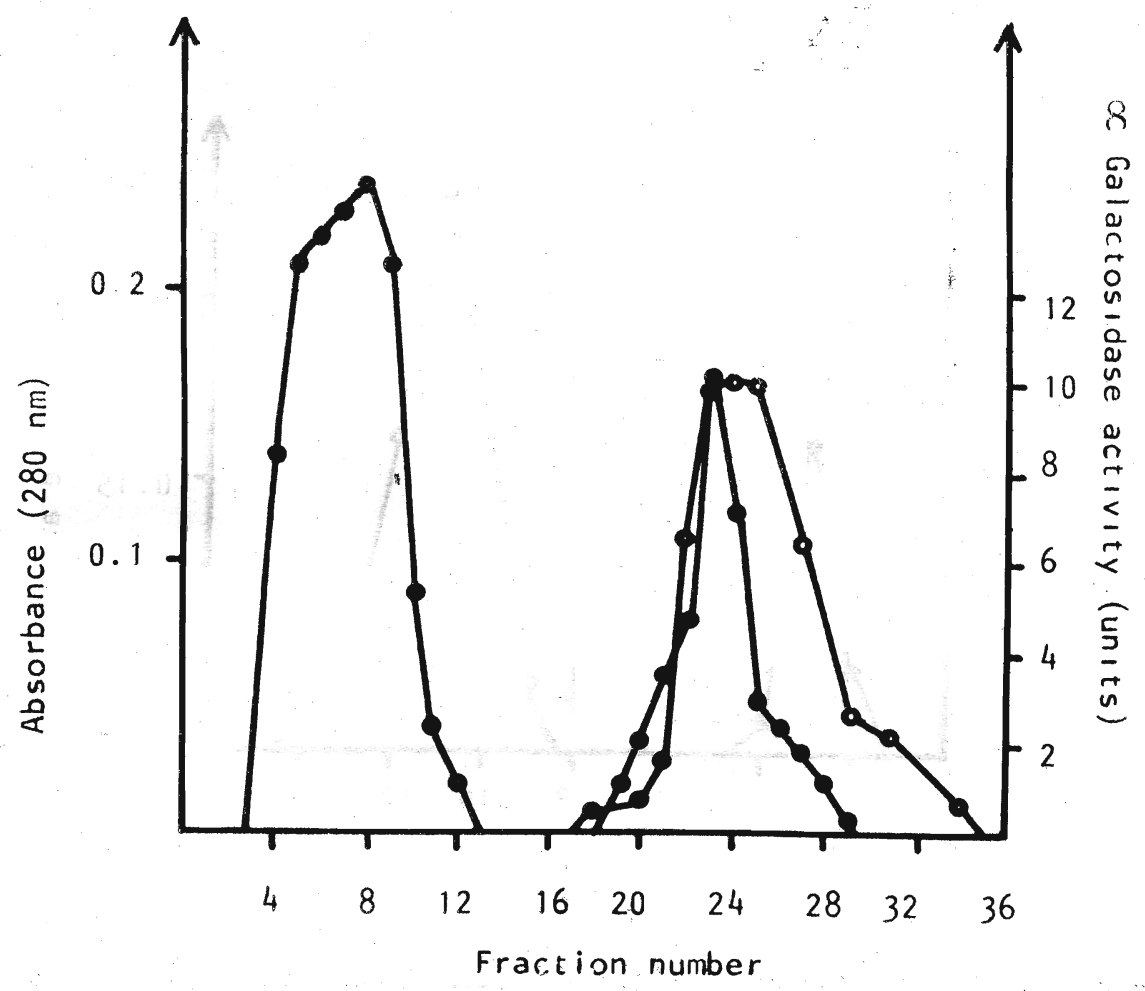

Figure 2: DEAE-Sephadox A-25 chromatography of $\alpha$-galactosidase. The columin 2.4 $\mathrm{x} 28 \mathrm{~cm})$ was eluted with a $2: 1$ gradient of $0.008 \mathrm{M}(200 \mathrm{ml}): 0.16 \mathrm{M}(100 \mathrm{ml})$ McIlvaine buffer (pH 5.5), flow rate was $30 \mathrm{ml} / \mathrm{h}$. and $10 \mathrm{ml}$ fractions were collected. Absorbance at $280 \mathrm{~nm} ; 0-0$, enzyme activity. 


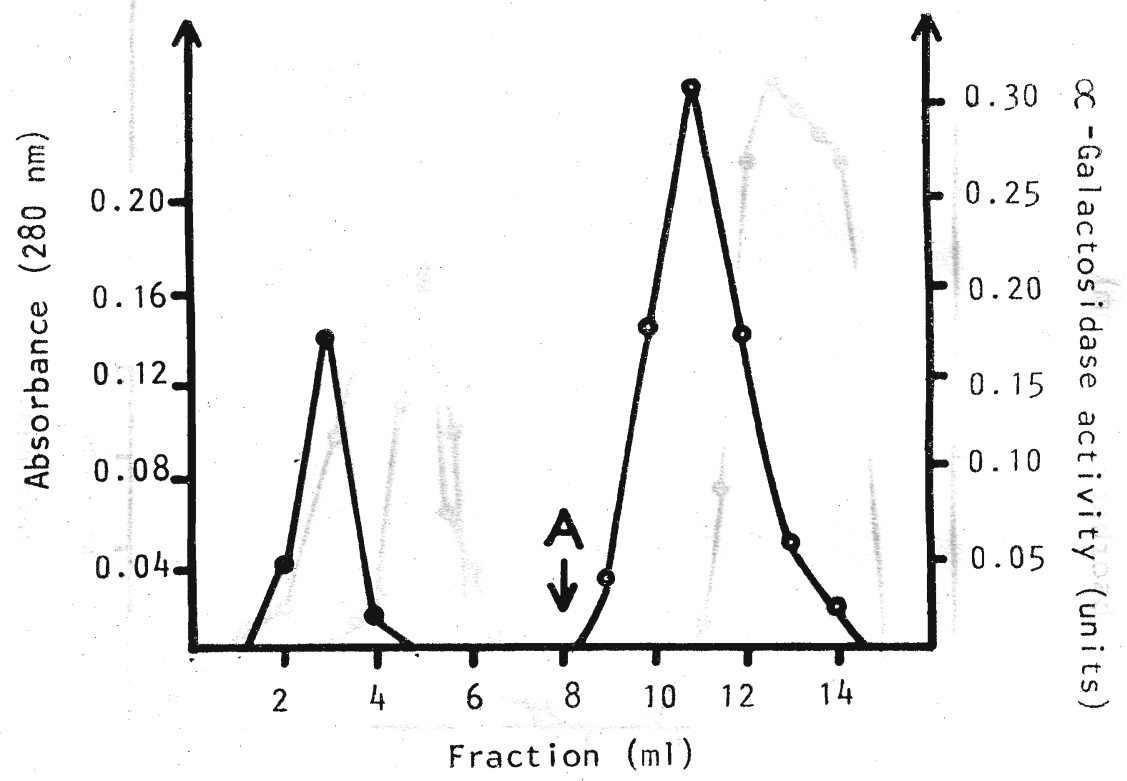

Figure 3: Affinity chromatography using Sepharose-4B-lysino-galacturonate column $(0.5$ $x 3 \mathrm{~cm})$. Applied $2 \mathrm{ml}(0.1 \mathrm{mg})$ of DEAE-Saphadex A- 25 eluted enzyme dialysed against $0.008 \mathrm{M}$ McIlvaine buffer ( $\mathrm{pH} 5.0$ ) and eluted with the same buffer. At $\mathrm{A}$, eluted with $0.1 \mathrm{M}$ McIlvaine buffer (pH 5.0). Flowrate $10 \mathrm{ml} / \mathrm{h}$, fraction volune $1 \mathrm{ml}$. - Absorbance at $280 \mathrm{~nm} ; 0-0$, Enzyme activity. 


\subsection{Preliminary purification of $\alpha$-galactosidase}

Preliminary purification of $\alpha$-galactosidase (Table 1 ) by acidification, $\left(\mathrm{NH}_{4}\right)_{2} \mathrm{SO}$ fractionation and DEAE-Sephadex A-25 chromatography gave on overall yield of $78 \%$ and the $\alpha$-galactosidase was purified 320 fold. DEAE-Sephadex A-25 chromatographic step (Figure 2) gave an 8 fold increase in purity (Table 1). When tested by polyacrylamide gel electrophoresis this enzyme solution had two protein bands and a single enzyme activity band.

\subsection{Purification by affinity chromatography}

In all affinity chromatography purifications DEAE-Sephadex A-25 eluted $\alpha$-galactosidase, dialysed against $0.008 \mathrm{M}$ Mcllvaine buffer $(\mathrm{pH} 5.0)$ was applied to the columns equilibrated with the same buffer. The control experiment showed that the dialysed enzyme when applied to a Sepharose-4B column was eluted out in void volume. This indicates that $\alpha$-galactosidase had no affinity to Sepharose-4B.

The synthesized Sepharose-4B-lysine-galactouronate gel had a bound lysine content of $124 \mu$ moles/ml and a galacturonic acid content of $112 \mu_{\text {moles }} / \mathrm{ml}$. The addition of large amounts of $\mathrm{CNBr}(330 \mathrm{mg} / \mathrm{ml})$ had probably led to a highly activated gel leading to increased coupling of the ligand. When DEAE-Sephadex A-25 eluted enzyme was applied to the column, contaminating proteins were eluted out with the same buffer while the enzyme was eluted out only with increasing molarity of the buffer (Figure 3). Specific activity of the purified enzyme was 20 units/mg protein. Recovery for the affinity chromatographic step was $86 \%$ and the capacity of the gel for $\alpha$-galactosidase was $42 \mu \mathrm{g} / \mathrm{ml}$.

The synthesized Sepharose-4B-lysine-galactosamine gel had a bound lysine content of $43 \mu_{\text {moles }} / \mathrm{ml}$ and the bound galactosamine content was $21 \mu_{\text {moles }} / \mathrm{ml}$. The DEAE-Sephadex A-25 eluted enzyme was only partially separated from contaminating proteins by this affinity gel (Figure 4). The synthesized $\mathrm{CH}-\mathrm{Sepharose-}$ $4 \mathrm{~B}$-galactosamine gel had a galactosamine content of $20 \mu_{\text {moles }} / \mathrm{ml}$. The major part of the enzyme applied to this column was eluted out by increasing the molarity of the buffer (Figure 5). Selected fractions were concentrated and the specific activity of the pooled enzyme was found to be 20 units/mg protein. The recovery for the purification step was $60 \%$. The capacity of the gel for $\alpha$-galactosidase was $4 \mu \mathrm{g} / \mathrm{ml}$.

Sepharose-4B-lysine-galactose-p-carboxyanilide gel had a lysine content of

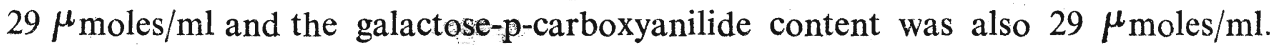
When the DEAE-Sephadex A-25 eluted enzyme was applied to this column, $50 \%$ of the enzyme was eluted out by increasing the morality of the buffer while the rest was eluted out by the substrate. (Figure 6). Both fractions were pooled dialysed and concentrated. The specific activity was determined to be 20 units/mg protein and the capacity of the gel for $\alpha$-galactosidase was $11 \mu \mathrm{g} / \mathrm{ml}$. The recovery for the purification step was $67 \%$. 


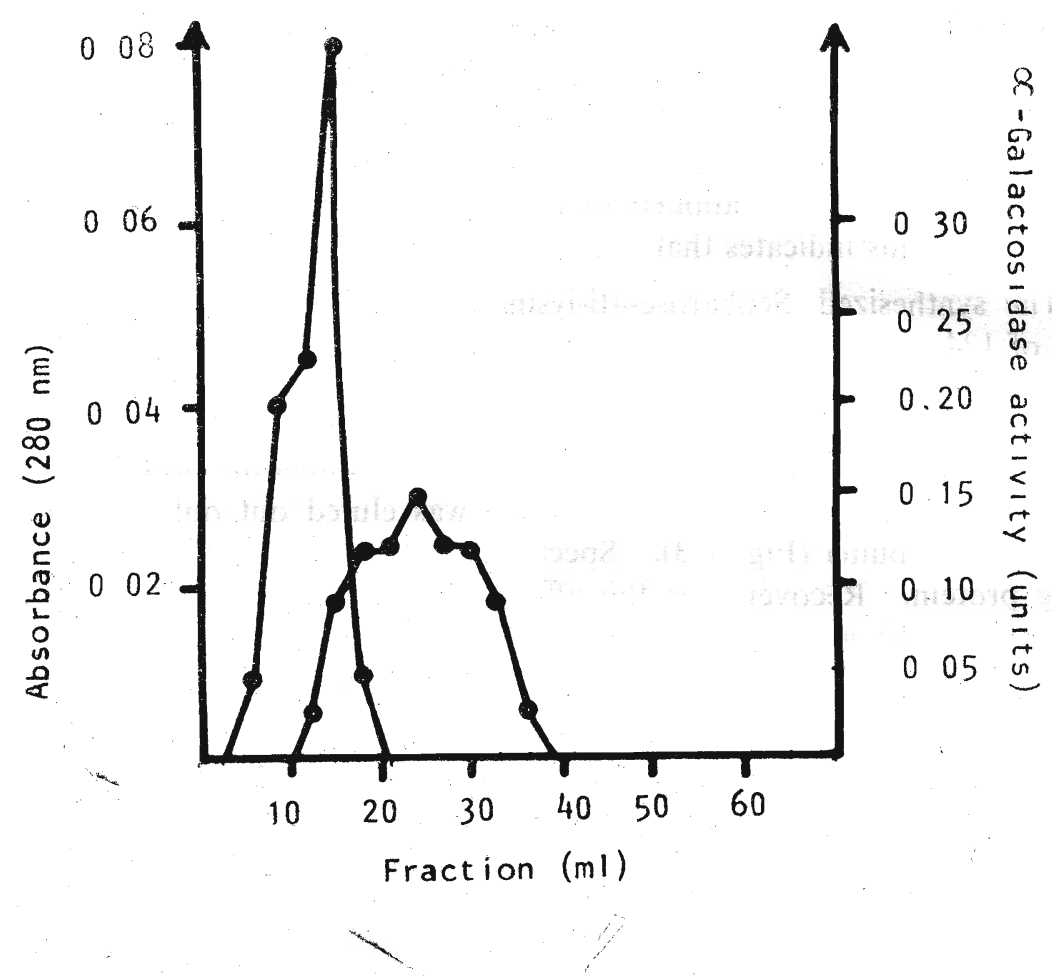

Figure 4: Affinity chromatography using Sepharose-4B-lysino-galactosamine column $(0.5$ x $8 \mathrm{~cm})$. Applied $2 \mathrm{ml}(0.1 \mathrm{mg})$ of DEAE-Sephadex A-25 eluted enzyme dialysed against $0.008 \mathrm{M}$ McIlvaine buffer (pH5.0). Eluted with the same buffer flowrate $10 \mathrm{ml} / \mathrm{h}$ and $3 \mathrm{ml}$ fractions were collected. Abserbance at $280 \mathrm{~nm} ; 0-0$ enzyme activity. 
TABLE 1. - Purification of $\alpha$-galactosidase from coconut endosperm

\begin{tabular}{|c|c|c|c|c|c|c|}
\hline Purification step & $\begin{array}{l}\text { Volume } \\
(\mathrm{ml})\end{array}$ & $\begin{array}{l}\text { Total enzyme } \\
\quad \text { activity } \\
\text { (units) }\end{array}$ & $\begin{array}{l}\text { Total protein } \\
\quad(m g)\end{array}$ & $\begin{array}{c}\text { Specific activity } \\
\text { (units/mg protein) }\end{array}$ & $\begin{array}{c}\text { Recovery } \\
(\%)\end{array}$ & $\begin{array}{l}\text { Purification } \\
\quad \text { (fold })\end{array}$ \\
\hline Extract & 650 & 228 & 10400 & 0.022 & 100 & 1 \\
\hline $\begin{array}{l}\text { Supernatant of extract } \\
\text { centrifuged at } 25000 \mathrm{~g}\end{array}$ & 550 & 215 & 2035 & 0.106 & 94 & 5 \\
\hline $\begin{array}{l}\text { Supernatant of Acidified solution } \\
\text { centrifuged at } 25000 \mathrm{~g}\end{array}$ & 660 & 211 & 264 & 0.799 & 93 & 36 \\
\hline Ammonium-sulphate fractionation & 140 & 182 & 196 & 0.929 & 80 & 42 \\
\hline DEAE-Sephadex A-25 chromatography & 422 & 177 & 25 & 7.08 & 78 & 322 \\
\hline $\begin{array}{l}\text { Affinity chromatography by } \\
\text { Sepharose-4B-lysine-galacturonate } \\
\text { column and concentration }\end{array}$ & 211 & 152 & 7.6 & 20.0 & 67 & 909 \\
\hline
\end{tabular}




\subsection{Polyacrylamide gel electrophoresis}

Polyacrylamide gel electrophoresis of purified $\alpha$-galactosidase having a specific activity of 20 units $/ \mathrm{mg}$ protein gave single and coincident protein and $\alpha$-galactosidase activity bands.

\section{Discussion}

Insoluble derivatives of 1-amino sugars have been successfully employed in the affinity chromatography of lectins. ${ }^{12} \mathrm{~N}-\mathcal{E}$-amino caproyl- $\mathrm{N}_{\mathcal{E}}$-aminocaproyl $x$-D-galactopyranosyl-Sepharose-4B conjugate was successfully used for purification of $\alpha$-galactosidase from coffee beans. ${ }^{13}$ This ligand is a competitive inhibitor of $\alpha$-galactosidase from coffee beans and the $\mathrm{Ki}$ value is $3 \times 10^{-4} \mathrm{M}$. As $\alpha$-D-galactophyranosylamine is not available commercially, we have used galacturonic acid, galactose-p-carboxyanilide and galactosamine (2-amino-2-deoxyD-galactopyranose) as affinity ligands.

Galactosamine (2-amino-2-deoxy-D-galactopyranose) does not inhibit a-galactosidase from coconut endosperm. Thus it is unsuitable for use as a affinity ligand. However CH-Sepharose-galactosamine gel has a weak affinity for a-galactosidase. This affinity is probably due to the hydrophobic properties of the spacerarm and the purification of $\alpha$-galactosidase by hydrophobic interaction chromatography is worth looking into.

Sepharose-4B-lysine-galactose-p-carboxyanilde gel has the highest affinity for $\alpha$-galactosidase though the capacity is lower than the Sepharose-4B-lysinegalacturonic acid gel. Decrease in capacity may be due to the lower ligand content of the immobilized galactose-p-carboxyanilide compared to the immobilized galacturonic acid. Both these gels could be used for purification of $\alpha$-galactosidase but the use of galacturonic acid ligand is preferable due to the ease in eluting the enzyme out of the column and as capacity and percentage recovery are also higher.

The percentage recovery for purification by Sepharose-4B-lysine-galacturonic acid gel is $67 \%$ and the specific activity is 20 units $/ \mathrm{mg}$ protein Both values are higher than the values obtained by purification using gel filtration. ${ }^{2}$ Recovery for gel filtration method is $12 \%$ and specific activity is 14 units $/ \mathrm{mg}$ protein. Increase in specific activity could be due to conversion of the low molecular weight isoenzyme to a higher molecular weight isoenzyme during purification by affinity chromatography. ${ }^{9}$

The authors are presently studying the use of hydrophobic ligands to purify $\alpha$-galactosidase from coconut endosperm. 


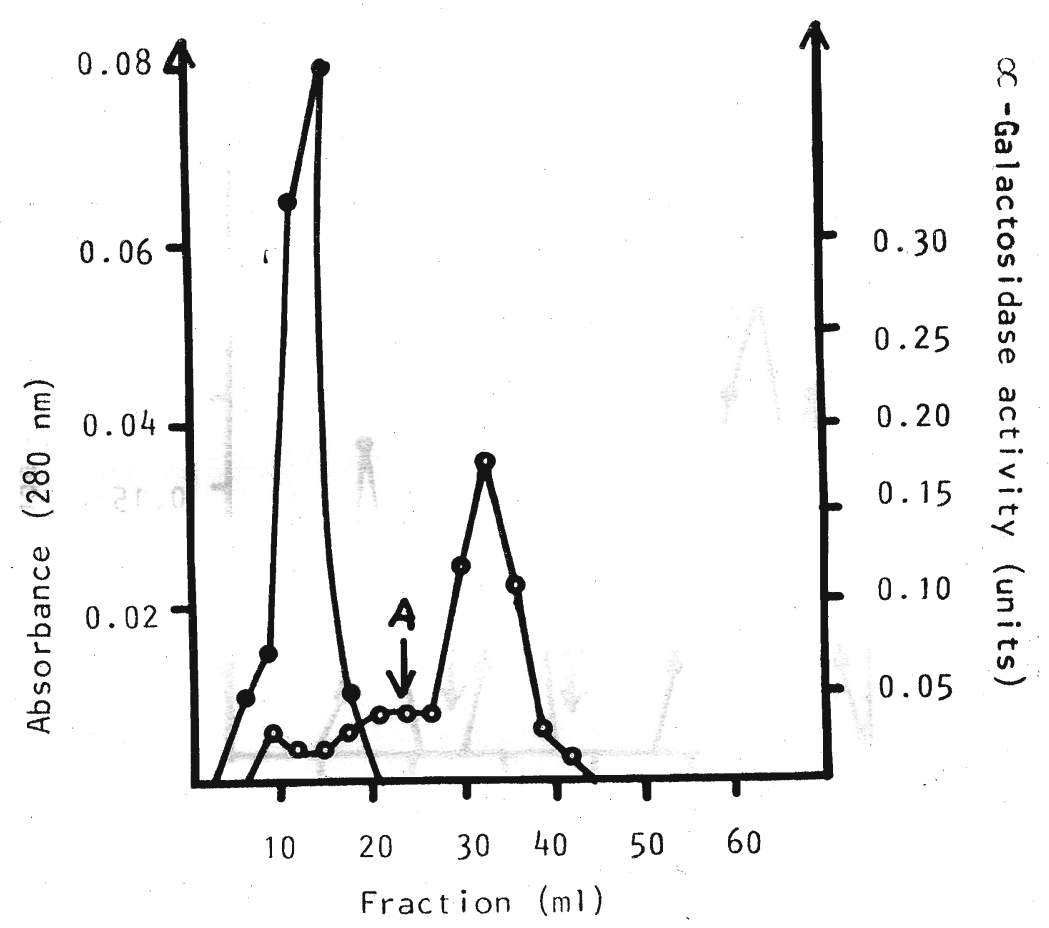

Figure 5: Affinity chromatography using CH-Sepharose-galactosamine column $(0.5 \times 8 \mathrm{~cm})$. Applied $2 \mathrm{ml}(0.1 \mathrm{mg})$ of DEAE-Sephadex A-25 eluted enzyme dialysed againts $0.008 \mathrm{M}$ McIlavaine buffer ( $\mathrm{pH}$ 5.0) and eluted with the same buff At A, eloted with $0.1 \mathrm{M}$ McIlvaine buffer ( $\mathrm{pH} 5.0$ ). Flow rate $10 \mathrm{ml} / \mathrm{h}$ and collected $3 \mathrm{ml}$ fractions , Absorbance at $280 \mathrm{~nm}$; O-O, enzyme activity. 


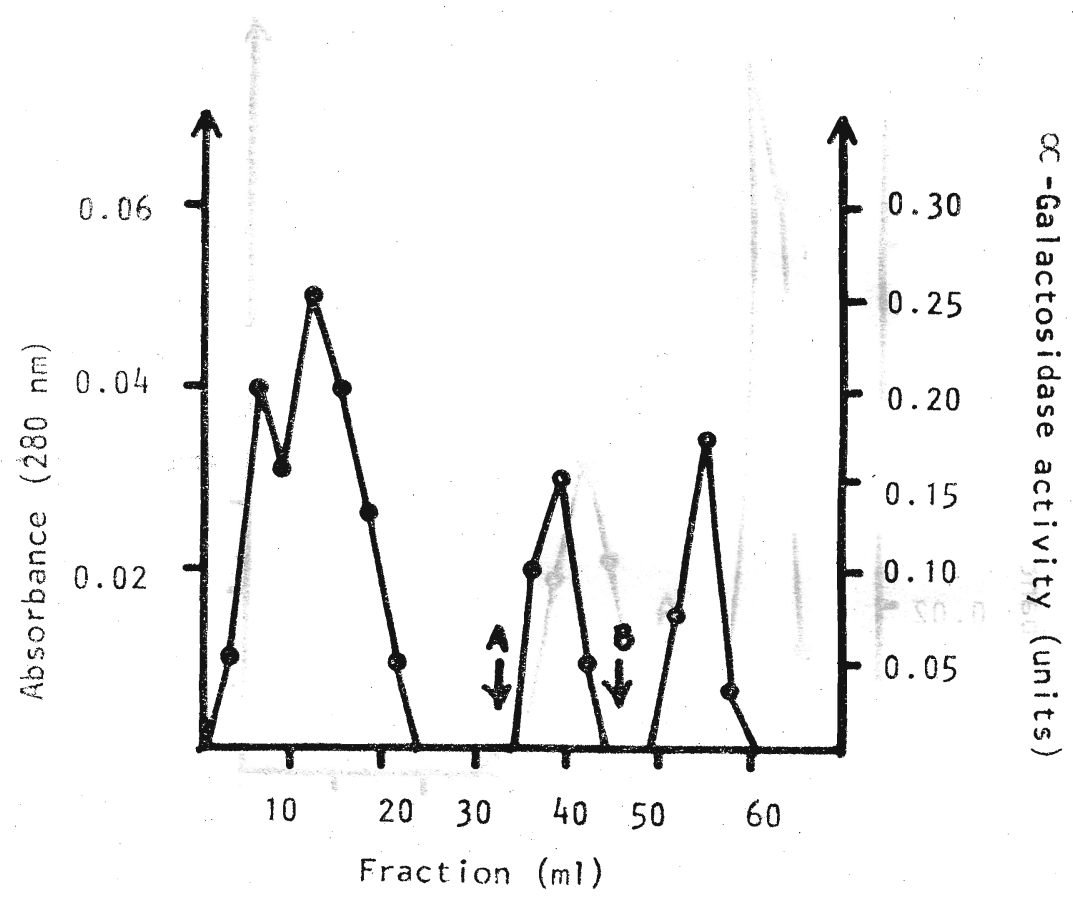

Higure 6: Affinity chromatography using Sepharose-4B-lysino galactose-p-carbozyanilie column $(0.5 \times 9.0 \mathrm{~cm})$. Applied $2 \mathrm{ml}$ of DEAE-Sephadex A-25 eluted enzyme dualysed against $0.008 \mathrm{M}$ Mcllvaine buffer $(\mathrm{pH} 5.0)$. Eluted with the same buffer and at $\mathrm{A}$, eluted with $0.1 \mathrm{M}$ Mcllvaine buffer ( $\mathrm{pH}$ 5.0), at B, eluted with p-nitrophenyla-D-galactopyranoside. - Absorbance at $280 \mathrm{~nm} ; 0-\mathrm{O}$, enzyme activity. 


\section{Acknowledgements}

The authors wish to thank the Natural Resources, Energy and Science Authority of Sri Lanka for awarding the research grant (RGB/82/25) to carry out this research and the University of Colombo for providing the facilities. The Technical Assistance of Mr. O. D. H. R. Weerasena and Mr. R. D. Sothary is greatly appreciated.

\section{References}

1. Balasubramaniam, K. (1976.). Food Sci. 41: 1370.

2. Balasubramaniam, K., Dey, P. M. \& Pridham, J. B. (1974). Biochem. Soc. Trans. 2: 1128 .

3. Balasubramaniam, K. \& Mathew, C. D. (1982). J. Natn. Sci. Coun. Sri Lanka, 10 (2): 195.

4. Carney, E. (1921). Philippines Agri. 10: 55 .

5. Cuatrecasas, P. (1970). J. Biol. Chem. 245: 3059.

6. Davis, B. J. (1964). Ann. N.Y. Acd. Sci., 121: 404.

7. Dey. P. M. (1978). Advan. Carbohyd. Chem., 37, 283.

8. Dey, P. M. (1980). Advan. Carbohyd. Chem., 35, 341.

9. Dey, P. M., Khaleque, A. \& Pridham, J. B. (1971). Biochem. J. 124: 27.

10. Dey, P. M. \& Pridham, J. B. (1969). Biochem, J., 113: 49.

11. Dubois, M., Gilles, K. A., Hamillton, J. K., Rebers, P. A. \& Smith, F. (1956). Analty. Chem., 28: 350.

12. Gordon, J. A., Blumerg, S., Lis, H. \& Sharon, N. (1972). Febs. Lett., $24: 193$.

13. Harpaz, N., Flowers, M. H. \& Sharon, N. (1974). Biochem. Biophs. Acta, $341: 213$.

14. Hartman, W. W. \& Dreger, E.E. (1943). In 'Organic syntheses', A. A. Blatt ed. John Wiley and Sons, New York.

15. Honeyman, J. (1963). In 'Methods in Carbohydrate Chemistry' $R$. L. Whistler and M. L. Weifrom ed. Academic Press. London.

16. Lowry, O. H., Rosenbrough, N. J., Farr, A. L. \& Randall, R. J. (1951). J. Biol. Chem. 193: 265.

17. Mapes, A. C. \& Sweely, C. C. (1973). J. Biol. Chem. 248: 2461.

18. McIlvaine, T. C. (1921). J. Biol. Chem. 49: 183.

19. Moore, S. \& Stein, W. H. (1948). J. Biol. Chem. 176: 367.

20. Stahl, E. \& Kaltenbach, U. (1965). In thin layer chromatography' E. Stahl. ed. Academic Press. London.

21. Wallenfels, K. \& Malfotra, O. P. (1961). Advan. Cambohyd, Chem. 16: 239. 